\title{
PILLANAT VAGY TÖRTÉNETI FOLYAMATOSSÁG: REKONSTRUKCIÓ ÉS/VAGY HELYREÁLLÍTÁS
}

\author{
FEJÉRDY TAMÁS \\ DLA, az ICOMOS MNB elnöke. E-mail: tfejerdy47@gmail.com
}

\begin{abstract}
A fizikai valóságában létező müemlék egy adott időmetszetben vizsgálva magán hordozza a megelözö története minden hatásának következményeit, a szándékolt és szándékolatlan beavatkozások eredőjeként. A mủemlék hordozta értékek továbbéltetése szorosan összefügg azzal, hogy milyen, nem csupán az anyagi dimenziókra vonatkozó rendeltetést szánnak az adott múemléknek. A történeti folyamatosság értelmezésében a mủemlékvédelmi gondolat 19. századi térnyerése óta jelen lévő, ugyanakkor jelentéstartalmában változó fogalmak-elvárások a müemlékként elismert javak hitelesége és integritása. Megörzésükhöz is elengedhetetlenül szükséges a konzerválás, a restaurálás, illetve mindenekelőtt a folyamatos gondozás - mindez szoros összefüggésben a rendeltetéssel, a fenntartó (és fenntartható) használattal. Felvetődhet a tervezett fejlesztés pillanatában már nem létező részek, meghatározó jelentőségü összetevők rekonstruálásának a gondolata. Az adott pillanatban rendelkezésre álló tudás, információk alapján születik döntés arról, hogy milyen volt, és hogy milyen/melyik legyen az a történeti folyamatosság, amelyet megjeleníteni szándékozunk. A konzerválást, restaurálást meghaladó mértékủ beavatkozások az adott pillanat, esetünkben a 21. század alkotásai. A rekonstruktív kiépítés igazolását alátámasztani kívánó módszerek, eszközök tárháza jelentősen bővült az információs technológia (IT) nyújtotta lehetőségekkel.

A rekonstrukció, bár elsődlegesen biztosan nem tekinthető múemlékvédelmi beavatkozásnak, bizonyos körülmények között ebben a körben is értelmezhető. Az időtényező meghatározó jelentőséggel bír e tekintetben. A töredékessé válás vagy a teljes pusztulás utáni nagyobb időtávlat után a rekonstruktív kiépítés kizárólag csak a friss beavatkozás pillanatnyi megközelítéséből vezethető le. A fizikailag fennmaradt értékek megőrzését, fenntarthatóságát szolgáló helyreállítás kiegészítésére az információs technológia számos, visszafordíthatatlan fizikai beavatkozással nem járó eszközt, megoldást is kínál. Az eltúlzott rekonstrukciós beavatkozás manipuláció: „Mostantól kezdve minden másképpen volt.”
\end{abstract}

Kulcsszavak: müemlék, rekonstrukció, hitelesség, integritás, időtényező

A mélyebb megértés érdekében - távolabbról indítva a gondolatmenetet - az értékalapú megközelítés meghatározó fontosságára érdemes rámutatni. A műemlék, történeti épület(együttes) által megtestesített-hordozott érték számos értéktényezöből tevődik össze, amelyek közül különböző időszakok eltérő megközelítés alapján emelik ki a számukra elsődleges fontosságú, ezért az adott korszaknak a mủemlékek mikénti értékelését, értelmezését, kezelését meghatározó értéktényező(ke)t. A külön- 
féle értéktényezők ${ }^{1}$ számbavétele messzire vezetne, így itt és most csak igen nagy vonalakban eshet erről szó.

Az európai mủemlékvédelmi gondolatnak a 19. századi kezdeteikor és fokozatos kibontakozásakor, ismert módon, éppen nem a gazdasági-anyagi megfontolás, azaz nem a használati érték volt elsődleges. Sokkal inkább a kiemelkedő művészeti, történeti-dokumentatív érték, a sajátosan egyedi karakter és mindenekelött az éppen formálódó nemzeti identitás(ok) megjelenítésében és megerősítésben játszott szerep. Ez határozta meg, hogy valamely alkotás, épület, épületegyüttes fennmaradását annak müemlékké minősítésével kívánták-e a jelen és a jövő számára biztosítani.

A müemlékek anyagi mivoltukban való létezése tényszerüen meghatározott adottságokat jelent: a fizikai valóságában létező müemlék, egy adott időmetszetben (jelen) vizsgálva, magán hordozza a megelőző története (múlt) minden - az anyagi mivoltában változásokat létrehozó - hatásának a következményeit, a szándékolt és szándékolatlan beavatkozások eredőjeként. A különféle behatások lenyomata igencsak különböző módon és mértékben látható-érzékelhető, értelmezhető - ezért a megismerhetőség lehetőségei és határai is esetről esetre változnak. E határok ugyan bizonyos mértékben tágíthatók a rendelkezésre álló, a kutatás-megismerés érdekében felhasználható eszköztár bővülésével, az alkalmazott módszerek tökéletesedésével, de azzal mindenképpen számolni kell, hogy a történeti periódusok időbeli, s a müemlék térbeli-fizikai alakulásának minden részletre kiterjedő, teljes körü megismerés legfeljebb csak elméletileg lehetséges - vagy talán még úgy sem. A történeti folyamatok komplexitása és visszafordíthatatlan jellege alázatra és nagy óvatosságra int, a múltra vonatkozó kategorikus megállapítások és a jövőt determináló jelen beavatkozások terén egyaránt.

A rendeltetéssel kapcsolatos szándékok: a müemlék hordozta értékek továbbéltetése (kiteljesítése) szorosan összefügg azzal, hogy milyen, a legszélesebb értelemben vett (nem csupán az anyagi dimenziókra vonatkozó) rendeltetést szánnak az adott müemléknek (jövő). Az építészeti alkotások, épületek és együtteseik meghatározó sajátossága, hogy konkrét használati céllal alkották meg azokat - eredetileg semmi sem épült „müemlék”-nek. A mai (illetve tegnapi, azaz 19-20. századi) értelemben vett müemlékvédelem léte elötti időre vonatkozóan ez nem is lett volna lehetséges... A konkrétan megemlékezés, emlékezés-emlékeztetés céllal létrehozott müvek sem voltak müemlékek: azok az emlékmü múfajába tartoznak. Ezekből ugyan a későbbi korok megbecsülése révén lehet müemlék is, de ez mit sem változtat az eredeti (nem müemléki mivoltukkal összefüggő) rendeltetésüknek az elsődlegességén. Mindebből az is következik, hogy müemlék szándékos létrehozása elvileg nem is lehetséges, tehát napjainkban is az a helyzet, hogy legfeljebb csak valamiféle mesterséges müemlékpótlék hozható létre. Ebből a szempontból pedig már alig van jelentősége annak, hogy az a bizonyos müemlékpótlék ,zöldmezős beruházásként” vagy egy töredékesen fennmaradt mủemlék saját maga emlékmüvévé való kiépítéseként valósul meg. Mégis: a fó különbség abban áll, hogy az utóbbi esetben a kiépítésnek a meg-

${ }^{1}$ Ld. pl. az Alois Riegl-féle „klasszikus” értékcsoportokat. 
lévő értékekre való hatása sajnos negatív is lehet, mint ahogyan az esetek túlnyomó többségében az is - a fennmaradt történeti szubsztanciának, a vizuális integritásnak, vagy egyszerre mindkettőnek a sérülését előidézve.

Témánk szempontjából kulcsfogalmak a „hitelesség” és az „integritás” mint az önazonosságot jelentő-hordozó minőségek. A történeti folyamatosság értelmezésében a müemlékvédelmi gondolat 19. századi térnyerése óta jelen lévő, ugyanakkor jelentéstartalmukban változó fogalmak-elvárások a müemlékként elismert javak hitelessége és integritása: ezeknek a követelményeknek a teljesítése a müemlék önmagával való azonosságának a garantálása. A hitelességnek a Velencei Charta által használt - akkoriban általánosan elfogadott, mintegy axiomatikus (és ezért nem is definiált) - fogalmára jelentős hatással volt a - nem utolsósorban az UNESCO 1972es, ún. világörökség egyezményének alkalmazása nyomán kibontakozó - „kulturális örökség globalizáció”. Az 1994-es „Narai Dokumentum a hitelességről” sokat hivatkozott, de bizonyos értelemben (a Velencei Chartához hasonlóan) gyakorta félreértelmezett iránymutatása látszólag egyfajta plurális értelmezést tesz lehetővé: egyaránt érvényesnek és elfogadandónak nyilvánítva a nagy kulturális régiók eltérő hitelességfogalmát. A félreértelmezés lehetősége, egyben a téves hivatkozási alap ugyanaz, nevezetesen: ha egy meghatározott kulturális régióban - mint például a mi európai régiónkban - egy másik kulturális régió - például az ázsiai - hitelességfogalmát alkalmazzák. Az európai hitelességfelfogás történeti kialakulása és kiteljesedése $^{2}$ szerint a történeti értéknek, a müemléknek a hitelességét elsősorban, illetve csaknem kizárólagosan a konkrét alkotásban, annak fizikai alkotó elemeiben ismeri el, kiemelkedő jelentőséget tulajdonítva az adott „darab” egyediségének, anyagában is fennálló önazonosságának. Az egyediség hangsúlyos szerepe a mi kulturális régiónkban egyáltalán nem véletlen - megrendelő, alkotó (és az utókor értékelése) oldaláról fontos tényező. Ehhez képest „közös” oldal: a tradicionális folyamatok, szerkesztési szabályok, az „üzenet” (spirituális tartalom), annyira másodlagosak, hogy a „hitelesítésben” játszott szerepük semmiképpen nem hasonlítható össze az ázsiai (kínai, koreai, japán) kultúrák esetében ismerttel, illetve elismerttel.

A hitelességgel kapcsolatban az előbbiekben kifejtetteknek első megközelítésben ellentmondani látszik az integritás követelménye, hiszen azt tartalmilag a „teljes körüség” és a „sértetlenség” kettős követelményével lehet leírni. Az, hogy ez az ellentmondás valójában csak látszólagos, ugyancsak a kulturális régiónkra vonatkozó értelmezésből vezethető le. Ugyanis a teljes körüségnek és sértetlenségnek kétféle lehetséges értelmezése van. Az egyik, amely a mi kulturális régiónkban érvényes, az ismét csak szorosan kapcsolódik a müemlék fizikailag létező, történetileg fennmaradt szubsztanciájához: éppen ennek a teljes körüségéről és sértetlenségéről van szó. A másik lehetséges értelmezés az - egyszerüség kedvéért - ázsiainak nevezhető megközelítés: a mindenkor az „eredeti”, elsődleges teljesség megőrzésére, és ha az

${ }^{2}$ Ld. Françoise Choay: Sept propositions sur le concept d'authenticite / Seven Propositions on the Concept of Authenticity. In: Nara Conference on Authenticity - Conference de Nara sur l'Authenticité. Japan/Japon 1994. Proceedings/Compte rendu. Edited by/Rédeacteur: Knut Einar Larsen. UNESCO - Agency for Cultural Affairs/Direction des Affaires Culturelles (Japan/Japon) - ICCROM - ICOMOS. 293-297. 297-301. 
sérült vagy elveszett, annak a visszaállítására való törekvés. A hasonlóság az európai müemlékvédelem kezdeteikor megvalósított, úgynevezett purista helyreállításokban megjelenő törekvéssel csak felszíni hasonlóság. Ez utóbbi ugyanis, bár valóban ugyancsak - idealizált - teljes körüség újbóli megalkotására törekszik, nem alapozhat sem szigorú, kánonszerü alapokon nyugvó szellemi-szerkesztési, sem technikai-technológiai folyamatosságra. Az időtlenségre törekedő teljes körüség és sértetlenség ázsiai modelljéhez képest a purista megközelítés éppen hogy az időbeliséget, a történetiséget kívánja felmutatni. Paradox módon, hiszen azt valójában éppen a müemléket alakító periódusok tudnák hitelesen megjeleníteni. A teljes körüség és sértetlenség meglétét éppen azzal lehet biztosítani, ha az nem csupán három dimenzióban valósul meg, hanem a negyedik dimenzió, az idő sem marad ki belöle.

Az előző, a gyakorlatban vitathatatlanul nagy kihívást jelentő követelmények teljesüléséhez a fizikai létezést biztosító, értékőrző és fenntartó beavatkozások is elengedhetetlenül szükségesek. Anyagban létező dolgokról lévén szó, nem kerülhető el azok konzerválása, restaurálása, illetve mindenekelött a folyamatos gondozásuk - s mindez szoros összefüggésben a rendeltetéssel, a fenntartó (és fenntartható) használattal. Mindez természetesen változásokkal, változtatásokkal is jár. Lényeges ugyanakkor annak hangsúlyozása, hogy a müemlékek esetében, amelyeket minden tekintetben megörizni vagyunk kötelesek, a változás önmagában sem nem cél, sem nem érték - éppen ellenkezöleg! Akkor és annyi fogadható el belöle, amikor és amennyi valóban elkerülhetetlenül szükséges.

A használói igények időbeni változása, ideértve a közösségi és társadalmi elvárásokat is, a fentieken túl - tehát a megörzéssel összefüggő „műszaki szükségességet” meghaladó mértékben is - szükségessé tehet jelentősebb, adaptációs/helyreállító beavatkozásokat is. Említettük, hogy semmi sem épült müemléknek, hanem a ma annak elfogadott alkotásokat annak idején valamilyen, a legszélesebb értelemben vett funkcionális igény kielégítésére hozták létre. Viszont ami már müemléki elismerést nyert az idők folyamán, annak ezáltal kettős funkciója lett, amelyek egyike éppen a „müemléksége”. Müemléke válogatja, hogy milyen mértékben szükséges dominánsnak tekinteni ezt a „müemlék funkciót” ahhoz a rendeltetéshez képest, amelyre az adott épületet amellett még igénybe veszik. Nyilvánvaló módon nem lehet cél, hogy a védett épületek minden esetben csupán saját müemléki mivoltukat szolgálják, bár ez sem zárható ki, főleg a töredékesen fennmaradt emlékek, romok esetében. Másrészről: az meg egészen biztosan nem lehet elfogadható törekvés, hogy a „mindenáron hasznosítás", funkcióba helyezés határozza meg valamely múemlék sorsának alakulását, háttérbe szorítva vagy rosszabb esetben károsítva-megszüntetve a müemlék immanens értékeit. Mint az élet annyi más területén, itt is a mindkét szempontot egyaránt és érdemben tekintetbe vevő megoldásra kell törekedni, azzal a sajátos kitétellel, hogy mivel a müemlék pótolhatatlan érték, lehetnek (vannak) olyan határok, amelyek átlépése semmilyen körülmények között nem engedhető meg - a rendeltetést szolgáló követelmények kielégítésére való hivatkozással sem.

Az értékmegőrzés követelményének elsődlegessége miatt az adaptációs/helyreállító, funkcióba helyező beavatkozások - akárcsak az általános értelemben vett kon- 
zerválás és restaurálás esetében - minden esetben széles körü tudományos megalapozottságot, körültekintő szakmai megközelítést és megfontolt döntéshozói magatartást igényelnek. Egyáltalán nem ellentmondás annak a hangsúlyozása, hogy a lehető legmélyebben és legrészletesebben elvégzett tudományos, és általában müemlékszakmai előkészületek alapozhatják meg leginkább a kettős feladat: az értékmegőrzés és a rendeltetésnek legjobban megfelelő kialakítás összhangjának a lehetőségét. $\mathrm{Az}$ ismeretek ugyanis nemcsak az értékek tudatos megörzésének a lehetőségét alapozzák meg, hanem a legtöbb esetben inspirációs forrásként vezethetnek rá a rendeltetés oldaláról nézve is optimális megoldás megtalálására.

A müemlék számára új rendeltetés biztosításának a szándéka során vetődhet/vetődik fel a korábban létezett, de a tervezett helyreállítás (fejlesztés?) pillanatában (idején) már nem létező részek, elemek, nagyobb vagy éppen meghatározó jelentőségü összetevők újraalkotásának, rekonstruálásának a gondolata, a rekonstrukciós motiváció, azaz a különböző (pl. identitásbeli, ideológiai, gazdasági, vallási) megfontolások alapján megfogalmazódó szándék. A lényegi, az eredményt meghatározó-minősítő kérdés természetesen az, hogy a következő, a szándék megvalósításához vezető lépésekben milyen mértékben van jelen a meglévő értékek tisztelete, azok sértetlenségének szem előtt tartása.

Általánosan elfogadott alapelv a „nil nocere!” A müemlékekkel kapcsolatban is érvényes, hogy a változtatások - elvételek vagy hozzátételek - nem eredményezhetik a meglévő értékek veszélyeztetését, még kevésbé azok eltủnését, ezért elsősorban e tekintetben kell vizsgálni a korábban megvolt, ún. történeti állapot visszaállításának lehetőségét is. ${ }^{3}$ A meglévő értékek köre, bár elsődlegesen az adott helyen a maguk fizikai valóságában jelen lévő elemekben testesül meg, nem szükül le csupán azok ilyen vagy olyan módon való megtartására. Érték lehet ugyanis a hagyományos megjelenés: látvány, rálátás, látkép is! Nem véletlen, hogy például a történeti tájak, de más, kiemelkedő egyedi müemlékek esetében is szorosan hozzájuk tartózónak tekintjük azokat a múvészeti alkotásokat, ábrázolásokat és leírásokat, amelyek az idők elörehaladtával keletkeztek és elválaszthatatlanul hozzájuk kapcsolódnak. A közös kultúra részeivé váltak, mégpedig nem önmagukban, hanem az ihlető forrásukkal együtt. Szándékosan távolabbról vett példaként a Római Fórum (és számos más antik rom) „töredékességében teljes”, generációk számára katartikus élményt jelentő megjelenésére érdemes utalni. Kevésbé ikonikus helyek, helyszínek, müemlékek esetében is mindig megfontolandó, hogy milyen jellegü és milyen mértékü változtatás, változás fogadható el, amely ezeket a részben fizikai, részben nem anyagi értékeket nem alakítják át olyan mértékben, hogy azok többé már nem lehetnek azonosak saját magukkal.

A döntés és a döntéshozók felelössége tehát nem csekély: adott pillanatban (jelen) rendelkezésre álló tudás, információk alapján dönteni arról, hogy milyen volt (múlt), és hogy milyen/melyik legyen (jövő) az a történeti folyamatosság, amelyet megőriz-

${ }^{3}$ Vö. Rigai Karta. In: Karták könyve. 2. bővített kiadás. Szerk.: Fejérdy Tamás. ICOMOS Magyar Nemzeti Bizottság Egyesület, Budapest 2011. 260-262. 
ni és/vagy megjeleníteni szándékozunk. A „múltról való tudásról dönteni” megfogalmazás arra mutat rá, hogy ez a tudás - amint arról korábban már esett szó - sajnálatos módon a legjobb szándék ellenére sem tud abszolút módon kiteljesedni. Nincs más lehetőség, mint az éppen ismert adatokra alapozni, amelyből többé-kevésbé valószínűsíthetö, egyes részletek vonatkozásában részlegesen vagy akár meglehetös pontossággal megállapítható, hogy a müemlékünk valamely eleme milyen lehetett, milyen volt egy bizonyos, ugyancsak kisebb-nagyobb pontossággal azonosítható történeti időmetszetben. Ha a fennálló bizonytalanságok ellenére valaminek az újbóli megalkotásáról születik döntés, annak fizikai, anyagba öntött megvalósításával az is eldől, hogy milyen múlt az, amelyet a magunkénak akarunk tudni. Ebben az esetben hangsúlyozott módon nem a müszaki-fenntarthatósági vagy akár bizonyos funkcionális szempontból szükségessé váló hozzátételekről van szó, hanem e hozzátételekhez, azok mikénti formálásához kapcsolódó szándékról.

Nem téveszthető szem elől, hogy a konzerválást, restaurálást meghaladó mértékü beavatkozások, függetlenül attól, hogy melyik építészeti koncepció: „kortárs megfogalmazás” vagy rekonstruktív „stílusban építés” alapján valósulnak meg, minden esetben az adott pillanat (korszak), esetünkben a 21. század alkotásai. A „müemlékes építész" is kortárs építész, bármenyire is igyekszik a beavatkozás során illeszkedni a meglévőhöz. Az ő munkája is kortárs építészeti beavatkozás, mint ahogyan mindig is szoros volt a kapcsolat egy-egy adott kor építészete és müemlék-helyreállításai között. ${ }^{4}$ Ismert dolog, hogy az értékes festmények hamisított változatai a hamisítás korának jegyeit is magukon viselik, ami miatt néhány évtizeddel később már nehéz elhinni, hogy miként is tudták a hamisítványt a hamisító kortársai eredeti alkotásnak elfogadni. Bizonyos értelemben hasonló a helyzet a müemlékek rekonstruktív kiépítésével kapcsolatban is, amint arra meggyőző példaként említhetjük a korai, „stílusban tartott" müemlék-helyreállításokat. Ahogyan azonban mindezek ellenére a festményhamisítás - éppen a megtévesztő mivolta miatt - továbbra sem tartozik az etikus cselekmények közé, ugyanez vonatkoztatható a mủemlékek elveszett részeit „pótló” rekonstrukciós beavatkozásokra is.

A müemlék-helyreállitás, illetve a rekonstrukciós kiépítés tétje az, hogy majdan melyik kategóriába fog tartozni az eredmény: a látható valóság vagy látszatvalóság lehetséges esetei közül. A lényegi különbség abban ragadható meg, hogy a müemlék-helyreállítás esetében a beavatkozás (ideális esetben nem hivalkodóan-elidegenítően, de) tényszerúen jelentkezik, szemben a rekonstruktív kiépítéssel, amelynek célja annak elhitetése, hogy amit létrehozott, az valamely (többé-kevésbé önkényesen kiválasztott) korábbi történeti korszak „eredeti” alkotásával azonos.

Korunkban igencsak nagy erejü, önbizalmat növelö támaszt jelent a rekonstruktív kiépítés esetében alkalmazott, a választott megoldás igazolását alátámasztani kívánó módszerek, eszközök tárházának jelentősen bővülése az információs techno-

\footnotetext{
${ }^{4}$ Vö. Román András: Elmélet arról, hogy mi szerint változik a mủemlékhelyreállítás felfogása. In: $A 27$. Egri Nyári Egyetem elöadásai 1997. Szerk. Kovács Erzsébet. Országos Múemlékvédelmi Hivatal, Budapest 1997. 49-53.
} 
lógia (IT) nyújtotta lehetőségekkel. Azt sugallja, hogy mint ahogyan az az elektronikus játékokban lehetséges, ami elveszett, az még feléleszthető: „Game over... de van még három életed..." Az információs technológia által nyújtott lehetőségeket természetesen nem szabad lebecsülni, hiszen valóban hihetetlen mennyiségü adat, adattöredék feldolgozását, különféle hipotézisek kidolgozását, ellenőrzését teszik lehetővé. A látványosan megjelenített elméleti rekonstrukciók viszont igen nagy kísértést jelentenek a fizikai megvalósításukra is, azt a látszatot keltve ugyanis, hogy a mai fejlett technikával már gyakorlatilag „minden lehetséges”. Vagy mégsem? Nem szabad ugyanis figyelmen kívül hagyni, hogy minden jelentősége és lehetősége ellenére is csupán segédeszközről van szó, amely nem tud hitelesebb, biztosabb eredményt elérni, mint az általunk ismert és betáplált adatok hitelessége. Az alkalmazása során követett szellemi megközelítés bizonyos értelemben hasonlítható valamiféle géntechnológiai megközelítéshez, a csontjaiban fennmaradt dinoszaurusz életre keltésének a kísérletéhez. Amelyről a csontok és egyéb nyomok alapján sok mindent tudunk már, esetleg csak éppen azt nem, hogy az illető lény tollas volt-e, vagy szőrős?

Más alkalommal már esett szó annak a veszélyéröl, hogyha a töredékes ismeretek alapján a jelenben döntjük el nagy határozottsággal, hogy milyen is volt a múlt. ${ }^{5}$ „Elöre a múltba”: a történeti alkotás ,saját DNS-ének” a felderítése a szándék, amiből azonban valójában legfeljebb egyfajta génmanipulált (GMO) eredményhez lehetséges eljutni, amely a töredékesen meglévő eredetit egyfajta rákos tovább- és túlnövekedéssel fedi (vagy éppen pusztítja) el. Mint minden hasonlat, bizonyára ez is sántít, de a nem kellőképpen megalapozott, mégis nagy határozottsággal megépített rekonstrukció a történeti megbízhatóság szempontjából éppoly „egészségtelen” lehet, mint a génmódosított élelmiszer...

Az előzők fényében ellentmondásosnak tünhet az a kijelentés, hogy a mủemlékvédelemben elfogadott jelentés szerinti rekonstrukció 6 , bár elsődlegesen biztosan nem tekinthető müemlékvédelmi beavatkozásnak, bizonyos körülmények között ebben a körben is értelmezhető. Valójában sajátos körülmények fennállása és meghatározott feltételek teljesítése-teljesülése esetén lehet ez így. ${ }^{7}$ Ezekben az esetekben valójában inkább az ,újbóli megépítés” az, ami történik. Az időtényező meghatározó jelentőséggel bír e tekintetben: a „pillanat” és a „történeti folyamatosság” összekapcsolódása egyedi esetének tekinthető az újjáépítés mint a rekonstrukció sajátos, gyakorlatilag a mủemlékvédelemben is elfogadható (példákkal bizonyíthatóan elfogadott) változata. Ami ezt megalapozza, az az idö, mint meghatározó jelentőségü

${ }^{5}$ Fejérdy Tamás: Mostantól kezdve minden másképpen volt? Müemlékvédelem 58 (2014) 1. 31-40.

${ }^{6}$ Nagy szükség volna a fogalmak egyértelmü használatára. A mindennapok gyakorlatában egyre jobban elterjedt a „rekonstrukció” kifejezés használata „müemlék-helyreállítás”, „rehabilitáció” értelemben, főleg a műemléki vonatkozású, nagyobb (többnyire EU-támogatással megvalósuló) projektek esetében.

${ }^{7}$ Fejérdy Tamás: A múemlékek, történeti épületek rekonstrukciója a nemzetközi dokumentumokban megfogalmazott iránymutatások tükrében / The reconstruction of Listed and Unlisted Historic buildings in the light of the Guidelines set Forth by the International Documents. Transsylvania Nostra 10 (2016) 4. 2-15. 
tényező. ${ }^{8}$ Azokban az esetekben, amelyekben a pusztulás bekövetkezte után „rövid” időintervallumon belüli újbóli megépítésről van szó, a rendelkezésre álló, különféle módokon rögzített és dokumentált adatok mellett a kortársak személyes ismerete nyújt (részben a hitelességet is alátámasztani tudó) nélkülözhetetlen információkat - és közösségi akarat követeli meg a többnyire valamilyen (természeti és/vagy ember által okozott) katasztrófa következtében elvesztett müemlék újraalkotását.

Ezek az esetek még csak össze sem hasonlíthatók azokkal, amelyekben a töredékessé válás vagy a teljes pusztulás utáni nagyobb - például több százados - időtávlat után jelenik meg a rekonstruktív kiépítés szándéka. Ha a kiépítés túlmegy a fenntarthatóságot szolgáló müszaki szükségesség minimumán, akkor az egészen biztosan nem értelmezhető újbóli megépítésként. Az adott alkotás folyamatos megléte ugyanis nemcsak ,epizódszerü", rövid időtartamra szakadt meg, ezért a rekonstruktív megépítés szándéka már kizárólag csak a tervezett friss beavatkozás pillanatnyi megközelítéséből vezethető le, amit azzal lehet a legjobban jellemezni, hogy „Mi megmondjuk, milyen volt a múlt".

Korunkat a vizualitás, a vizuális megismerhetőség igényének erőteljes megjelenése jellemzi. Ennek azonban nemcsak az lehet a módja, hogy a valamikori állapotot konkrét anyagban, újjáépítéssel adjuk vissza. Az alapkérdés tehát a „megépítés versus megjelenítés". Minden olyan esetben, amely kívül marad az előzőkben felvázolt „azonnali” újbóli megépítés esetkörén, a valóban korrekt megoldás a tényleges müemlék-helyreállítás, amilyen mértékben az hitelesen megvalósítható, kiegészítve a virtuális rekonstrukcióval. A fizikailag fennmaradt értékek megőrzését, fenntarthatóságát szolgáló helyreállítás kiegészítésére az információs technológia számos, viszszafordíthatatlan fizikai beavatkozással nem járó eszközt, megoldást is kínál a müemlékek értelmezésére, élményszerü bemutatására. Mégpedig nemcsak egyetlen kiválasztott időmetszetben, mint a „kőben-fában-téglában” megépített rekonstrukció, hanem az akárhány egymást követő periódus esetében is.

A jövő alapja a müemléki értékek megörzése területén is a múlttal együtt élő jelen. Az eltúlzott (mert megalapozatlan, hitelesen megalapozhatatlan) rekonstrukciós beavatkozás valójában egyfajta orwelli manipuláció: „Ettől kezdve minden másképpen volt." Az eredmény nem egy megújult müemlék, hanem a korábbi müemlék helyén álló valami: a müemlék - a saját maga emlékmüvévé átépítve. Amilyen mértékben átveszi az ilyen rekonstrukciót is megengedő, sőt megünneplő felfogás szerint megújított, újra- vagy inkább: újjáalkotott örökség a történelem helyét ${ }^{9}$, olyan mértékben gyengül annak az igazi identitást alakító-hordozó ereje. Nem volna szabad lebecsülni a befogadó: a személyek, közösségek, a társadalom képességét, és azt gondolni, hogy számukra a múlt csak a díszletszerüen „,teljes” és „,töké-

\footnotetext{
${ }^{8}$ Tamás Fejérdy: Authenticité dans la restauration des monuments historiques. In: Nara Conference on Authenticity - Conference de Nara sur l'Authenticité. Japan/Japon 1994. Proceedings/Compte rendu. Edited by/Rédeacteur: Knut Einar Larsen. UNESCO - Agency for Cultural Affairs/Direction des Affaires Culturelles (Japan/Japon) - ICCROM - ICOMOS. 211-217. 311-315.

${ }^{9}$ Utalás Sonkoly Gábornak az MTA Építészetelmélet, Építészettörténeti és Müemléki Állandó Bizottsága egy korábbi ülésén elhangzott gondolatára.
} 
letes" alkotásai révén válik megismerhetővé. Ezzel szemben a kevesebb: több! Vajon kinek jutna eszébe kiegyenesíteni a Magyar Szent Koronának a 17. század óta ferdén álló keresztjét?

\title{
PRIORITY OF THE PRESENT - OR HISTORICAL CONTINUITY (RECONSTRUCTION OR RESTORATION)
}

\begin{abstract}
Summary
The physical reality of the existing monuments in a particular moment bears all the consequences of any impacts received during its previous history, regardless of whether or not interference/interventions was/were done intentionally. Conservation and future life of the values embodied in a monument closely related to what is intended function, in its broadest sense - not only with regard to the material dimension. In the interpretation of historical continuity since the idea of conservation in the 19th century gaining ground, the concepts-requirements of authenticity and the integrity. Interventions to ensure physical existence are indispensable: conservation-preservation, restoration, and, above all, the continual maintenance - all are closely linked to the function and to the sustainable and sustaining use. Looking for adequate answers to contemporary needs could raise the idea of re-constructing decisive components which no longer exist more at the very moment. There are many possible motives, e.g. identity, ideological, economic, religious. The decision about what was and what/which one is the historical continuity intended to be displayed is brought on the basis of information, knowledge available at a given time. Interventions excessing conservation and restoration are products of the given moment, in this case the works of the 21 st century. In the case of reconstruction, tools have greatly expanded through the opportunities offered by information technology (IT).

Reconstruction, although it is certainly not considered as a primary conservation intervention, under certain conditions can be interpreted in this round too. The time factor is of decisive importance in this respect. Reconstructions taking place after a longer period following deterioration or the total loss of monuments can only be understood as works of the present commemorating past values and - in the best cases - serving the future life of communities. Unlike a built reconstruction, by using IT presentation several historic periods could be visualized without harming existing values. The excessive reconstruction intervention is actually a form of manipulation.
\end{abstract}

Keywords: historic monuments, reconstruction, authenticity, integrity, the time-factor 